\title{
PENGARUH REDESAIN KURSI GAZEBO FIK YANG ERGONOMIS TERHADAP MUSCULOSKELETAL DISORDER
}

\author{
Silvia Trias Putri, Solichin, Erianto Fanani \\ Fakultas Ilmu Keolahragaan Universitas Negeri Malang \\ E-mail: silvia.trias916@gmail.com
}

\begin{abstract}
Based on preliminary survey of student in FIK UM who sitting in gazebo FIK chair, there are $72.7 \%$ student that not comfortable while sitting in gazebo FIK, because of the buttock on the edge of the chair (63.6\%), the chair is not high enough (45.5\%), the chair has a long distance with the table (45.5\%). Perceived symptoms such as upper back pain (39.4\%), waist pain (36.4\%), lower back pain (30.3\%), and buttock pain (33.3\%). It is because of the chair design is not appropriate with the user anthropometry. The purpose of the research is to know the effect of redesigning ergonomic gazebo FIK's chair to musculoskeletal disorders of student in FIK UM. The research is a Pre Experimental with one group pretest and posttest design. The sample of this research is 49 people, who selected by using purposive sampling. Based on statistic test, it found that $P$ Value $0.000<0.05$ which is significant, it means that there is different of average value before and after redesign. The conclusion of the research is there is an effect of redesigning ergonomic gazebo FIK chair to musculoskeletal disorder of student in FIK UM
\end{abstract}

Keywords: redesign, ergonomic, chair, musculoskeletal disorders.

Abstrak: Berdasarkan survei pendahuluan pada mahasiswa Fakultas Ilmu Keolahragaan Universitas Negeri Malang (FIK UM) yang sedang duduk di gazebo FIK, sebanyak 72,7\% mahasiswa mengeluh tidak nyaman saat duduk di gazebo FIK. Keluhan tersebut dikarenakan duduk dengan posisi pantat berada diujung kursi gazebo FIK (63,6\%), kursi gazebo FIK kurang tinggi (45,5\%), kursi gazebo FIK memiliki jarak yang terlalu jauh dengan meja (78,7\%). Keluhan yang dirasakan antara lain sakit pada punggung $(39,4 \%)$, sakit pada pinggang $(36,4 \%)$, sakit pada bokong (30,3\%), dan sakit pada pantat (33,3\%). Keluhan-keluhan tersebut disebabkan desain kursi yang tidak sesuai dengan antropometri pengguna. Tujuan penelitian ini untuk mengetahui pengaruh redesain kursi gazebo FIK yang ergonomis terhadap musculoskeletal disorders pada mahasiswa FIK UM. Metode penelitian yang digunakan dalam penelitian ini adalah Pre Eksperimental dengan rancangan penelitian one group pre test and post test design. Sampel dalam penelitian ini sebanyak 49 orang, yang dipilih dengan menggunakan teknik purposive sampling. Hasil analisis perbedaan keluhan muskuloskeletal sebelum dan sesudah redesain dengan menggunakan uji wilcoxon diperoleh $p$ value $0,000<0,05$ yang bermakna signifikan, artinya ada perbedaan nilai rata-rata sebelum dan sesudah redesain kursi gazebo FIK. Kesimpulan dari penelitian ini adalah ada pengaruh redesain kursi gazebo FIK terhadap musculoskeletal disorders pada mahasiswa FIK UM.

Kata kunci: redesain, kursi, ergonomi, gangguan muskuloskeletal. 
Kampus merupakan sarana pendidikan bagi mahasiswa untuk berkembang menjadi pribadi yang aktif dan kreatif. Mahasiswa mempunyai berbagai aktivitas, baik itu yang berhubungan dengan akademik maupun non akademik, sehingga mahasiswa membutuhkan tempat yang cukup dalam memenuhi kegiatan-nya untuk berinteraksi satu sama lain (Sari, 2013). Salah satu tempat yang dapat digunakan mahasiswa untuk saling berinteraksi di Fakultas Ilmu Keolahragaan Universitas Negeri Malang (FIK UM) adalah gazebo FIK. Gazebo FIK tersebut dilengkapi dengan fasilitas seperti jaringan internet, kursi dan meja, serta memiliki atap pada bangunannya.

Berdasarkan survei pendahuluan melalui kuesioner pada 33 mahasiswa FIK UM yang sedang duduk di gazebo FIK, sebanyak $48,5 \%$ mahasiswa duduk di gazebo FIK selama 15-30 menit sambil melakukan aktivitas seperti berdiskusi, menggunakan laptop, dan menulis. Sebanyak $72,7 \%$ mahasiswa merasa tidak nyaman saat duduk di gazebo FIK. Mahasiswa merasa tidak nyaman saat duduk di gazebo FIK karena duduk dengan posisi pantat berada diujung kursi gazebo FIK 63,6\%, kursi gazebo FIK kurang tinggi 45,5\%, kursi gazebo FIK memiliki jarak yang terlalu jauh dengan meja $78,7 \%$.

Selain itu, berdasarkan survei pendahuluan dengan menggunakan kuesioner Nordic Body Map (NBM), sebanyak $75,8 \%$ mahasiswa merasakan pegal-pegal, dengan keluhan sakit pada punggung $39,4 \%$, sakit pada pinggang $36,4 \%$, sakit pada bokong 30,3\%, dan sakit pada pantat 33,3\%. Keluhankeluhan tersebut disebabkan desain kursi yang tidak sesuai dengan antropometri pengguna. Akibat dari penggunaan kursi yang tidak sesuai dengan ukuran tubuh, maka dapat menyebabkan perasaan tidak nyaman, seperti pegal-pegal, nyeri, dan kesemutan pada bagian tubuh.

Secara umum gangguan muskuloskeletal berawal dari ketidaknyamanan. Ketidaknyamanan ini akan berkembang menjadi musculoskeletal disorders apa- bila tidak diberikan upaya pengendalian (Lisdiana, 2013). Musculoskeletal disorders adalah suatu kondisi yang mempengaruhi sistem muskuloskeletal yang dapat terjadi pada tendon, otot, sendi, pembuluh darah, dan atau saraf pada anggota gerak. Gejala dapat berupa nyeri dan kebas pada bagian yang terlibat dan dapat berbeda derajat keparahannya mulai dari ringan sampai kondisi berat (HSE, 2012). Prevalensi kasus musculoskeletal disorders di Inggris Raya pada tahun 2014 mencapai 553.000 dari 1.243 .000 total penyakit yang berhubungan dengan pekerjaan, atau sebesar 44\% (HSE, 2015).

NIOSH menyebutkan bahwa ada 5 upaya pengendalian bahaya $\mathrm{K} 3$, yaitu eliminasi, subtitusi, engineering control, administrative control, dan penggunaan APD (NIOSH, 2015). Salah satu penyelesaian masalah ketidaknyamanan yang disebabkan oleh desain kursi gazebo FIK yang tidak sesuai dengan antropometri pengguna yaitu engineering control (perancangan) yang berupa modifikasi/perancangan agar tempat kerja lebih aman (NIOSH, 2015). Berdasarkan uraian masalah diatas, peneliti bermaksud melakukan penelitian yang bertujuan untuk mengetahui pengaruh redesain kursi gazebo FIK yang ergonomis terhadap musculoskeletal disorders pada mahasiswa FIK UM. Pengaruh redesain kursi gazebo FIK yang ergonomis terhadap keluhan muskuloskeletal dapat diketahui dari adanya perbedaan tingkat kenyamanan dan tingkat keluhan yang dirasakan pada saat sebelum dan sesudah duduk di kursi gazebo FIK yang ergonomis.

Ergonomi sendiri merupakan ilmu yang mempelajari hubungan antara peralatan, pekerjaan, sistem, organisasi, dan lingkungan dengan kemampuan dan keterbatasan manusia sehingga tercapai suatu lingkungan yang harmonis (Iridiastadi, 2014). Secara singkat dapat dikatakan bahwa ergonomi adalah suatu prinsip fitting the job to the man, yang artinya pekerjaan harus disesuaikan dengan kemampuan dan keterbatasan 
yang dimiliki oleh manusia. Hal ini menegaskan bahwa suatu jenis pekerjaan perlu memperhitungkan keterbatasan manusia sebagai pelaku kerja (Solichin, 2014). Menurut Kroemer dalam Iridiastadi (2014:5), tujuan penerapan ergonomi dapat dibuat dalam suatu hierarki dengan tujuan yang paling rendah adalah sistem kerja yang masih dapat diterima (tolerable) dalam batas-batas tertentu, asalkan sistem ini tidak memiliki potensi bahaya terhadap kesehatan dan nyawa manusia.

Dalam hierarchy of control, salah satu pengendalian bahaya yang berkaitan dengan ergonomi seperti desain yang buruk yaitu dengan cara engineering control. Engineering control yang dapat dilakukan berupa redesain. Redesain adalah proses perencanaan dan perancangan untuk melakukan suatu perubahan dengan cara menyesuaikan orang yang menggunakannya khususnya yang menyangkut dimensi ukuran tubuh, sehingga user (pengguna) merasa nyaman (Wiranata, 2011). Redesain bertujuan untuk melakukan suatu perubahan pada suatu desain dengan cara menyesuaikan antropometri pengguna dengan desain, sehingga user (pengguna) akan merasa nyaman saat menggunakan desain tersebut.

Antropometri sendiri berasal dari kata antropos yang berarti manusia, dan metrikos yang berarti pengukuran. Antropometri adalah suatu studi yang berkaitan dengan pengukuran dimensi tubuh manusia (Solichin, 2014). Adapun faktor-faktor yang mempenga-ruhi antropometri adalah (Iridiastadi, 2014): usia, jenis kelamin, ras/etnis, pekerjaan/aktivitas, dan kondisi sosioekonomi.

Suatu perancangan tempat duduk harus diupayakan sedemikian rupa sehingga berat badan yang disangga oleh tulang duduk tersebar pada daerah yang cukup luas. Bertahan pada posisi duduk dalam jangka waktu yang lama tanpa mengubah-ubah posisinya dapat menyebabkan kurangnya aliran darah pada suatu daerah (ischemia), gangguan pada sirkulasi darah dapat menyebabkan nyeri, sakit, dan rasa kebal (mati rasa). Sehubungan dengan hal ini, data antropometri yang tepat sangat diperlukan untuk dapat menentukan pengukuran-pengukuran yang tepat (Panero, 2003). Dimensi-dimensi dasar yang ada pada umumnya dapat diterima sebagai pedoman perancangan tempat meliputi tinggi duduk, lebar duduk, lebar tempat duduk, tinggi sandaran punggung, tinggi sandaran lengan, dan jarak antar sandaran lengan (Panero, 2003). Adapun faktor-faktor yang mempengaruhi kenyamanan penggunaan kursi antara lain karakteristik tempat duduk dan karakteristik pekerjaan yang meliputi lama duduk dan aktivitas.

Akibat ketidaknyamanan saat duduk maka dapat menimbulkan keluhan musculoskeletal disorders. Musculoskeletal disorders atau gangguan muskuloskeletal adalah suatu kondisi yang mempengaruhi sistem muskuloskeletal yang dapat terjadi pada tendon, otot, sendi, pembuluh darah, dan atau saraf pada anggota gerak. Gejala dapat berupa nyeri dan kebas pada bagian yang terlibat dan dapat berbeda derajat keparahannya mulai dari ringan sampai kondisi berat (HSE, 2012).

Faktor-faktor yang dapat menyebabkan keluhan muskuloskeletal antara lain: 1) postur tubuh (Astuti, 2009:20) berupa; personal factor seperti umur, antropometri, riwayat penyakit, cedera, task requirements seperti jenis aktivitas, waktu istirahat, dan workspace design seperti dimensi tempat duduk, 2) lama duduk (Sumekar, 2010) desain kursi kerja (Panero, 2003).

\section{METODE}

Rancangan penelitian yang digunakan dalam penelitian ini adalah pre-eksperimental dengan desain one group pretest and posttest design, karena masih terdapat variabel luar yang ikut terhadap terbentuknya variabel terikat, jadi hasil eksperimen yang merupakan variabel terikat bukan sepenuhnya dipengaruhi oleh variabel bebas (Sugiyono, 2011). 
Populasi target dalam penelitian ini adalah mahasiswa FIK yang duduk di gazebo FIK. Sedangkan populasi terjangkaunya yaitu kapasitas atau daya tampung kursi gazebo FIK. Adapun kapasitas mahasiswa yang dapat duduk di gazebo FIK adalah 56 orang. Berdasarkan perhitungan sampel dengan menggunakan rumus Isaac dan Michael (Sugiyono, 2011:69), ukuran sampel minimal dalam penelitian ini adalah 49 orang. Teknik pengambilan sampel menggunakan purposive sampling, dengan kriteria inklusi sebagai berikut: 1) mahasiswa aktif Fakultas Ilmu Keolahragaan Universitas Negeri Malang yang duduk di gazebo FIK dan bersedia menjadi sampel penelitian, 2) memilih sampel yang tidak mempunyai riwayat penyakit yang berkaitan nyeri punggung (rheumatic, osteoporosis, kifosis, dan lordosis), 3) memilih sampel yang tidak memiliki cedera atau patah tulang (fraktur) di bagian tulang punggung.

Dalam penelitian ini terdapat 2 variabel yaitu variabel independen dan variabel dependen. Variabel independen adalah variabel yang mempengaruhi atau yang menjadi sebab perubahannya atau timbulnya variabel dependen (Sugiyono, 2011). Variabel independen dalam penelitian ini adalah redesain kursi gazebo FIK. Variabel dependen yaitu variabel yang dipengaruhi atau yang menjadi akibat karena adanya variabel bebas (Sugiyono, 2011:4). Variabel dependen dalam penelitian ini yaitu musculoskeletal disorders.

Adapun instrumen penelitian ini yaitu sebagai berikut: 1) meteran, yang berfungsi untuk mengukur dimensi kursi gazebo FIK dan juga dimensi tubuh mahasiswa Fakultas Ilmu Keolahragaan, 2) kuesioner tingkat kenyamanan, digunakan untuk mengetahui tingkat kenyamanan mahasiswa Fakultas Ilmu Keolahragaan saat duduk di gazebo FIK. Pengukuran tingkat kenyamanan menggunakan pertanyaan pilihan ganda dan diberikan skor 1 untuk pilihan jawaban A yang artinya risiko untuk terkena gangguan muskuloskeletal tidak ada (tidak sakit), skor 2 untuk pilihan jawaban B yang artinya sudah ada risiko untuk terkena gangguan muskuloskeletal (agak sakit), skor 3 untuk pilihan jawaban $\mathrm{C}$ yang artinya ada risiko untuk terkena gangguan muskuloskeletal (sakit), dan skor 4 untuk pilihan jawaban D yang artinya risiko untuk terkena gangguan muskuloskeletal sangat tinggi (sangat sakit), 3) kuesioner Nordic Body Map (NBM), digunakan untuk mengetahui adanya musculoskeletal disorders sebelum dan sesudah duduk di kursi gazebo FIK yang ergonomis. Pengukuran tingkat kesakitan dengan cara memberikan tanda centang $(\sqrt{ })$ pada kolom 1 jika tidak ada keluhan (tidak sakit), kolom 2 jika agak sakit, kolom 3 jika merasakan sakit pada bagian tubuh tertentu, dan kolom 4 jika merasakan sangat sakit pada bagian tubuh tertentu.

Skala pengukuran yang digunakan dalam penelitian ini adalah ordinal. Dengan demikian teknik analisis data yang digunakan untuk penelitian ini adalah Uji Wilcoxon. Uji Wilcoxon ini dipergunakan untuk menguji perbedaan dua sampel yang berpasangan pada skala data ordinal (Suliyanto, 2014). Uji statistik penelitian ini dilakukan dengan menggunakan software komputer.

\section{HASIL}

\section{Kondisi Subjek Penelitian}

Berdasarkan kuesioner tingkat kenyamanan yang telah disebarkan kepada 49 responden, hasil uji hipotesis untuk perbedaan nilai rata-rata sebelum dan sesudah redesain kursi gazebo FIK pada pertanyaan tentang frekuensi duduk, posisi pantat, kecukupan ketinggian kursi, perlunya adanya tambahan tinggi kursi, kecukupan jarak kursi dengan meja, perlunya adanya tambahan lebar kursi, keluhan pegalpegal, nyeri, dan kesemutan, serta munculnya keluhan, diperoleh $p$ value $0,000 \quad(\mathrm{P} \leq 0,05)$ yang bermakna signifikan. Berikut adalah distribusi frekuensi kuesioner tingkat kenyamanan. 
Tabel 1. Kuesioner Tingkat Kenyamanan

\begin{tabular}{lccccc}
\hline \multirow{2}{*}{\multicolumn{1}{c}{ Distribusi Frekuensi }} & \multicolumn{2}{c}{ Pretest } & \multicolumn{2}{c}{ Posttest } & \multirow{2}{*}{ P Value } \\
\cline { 2 - 5 } & Mean & SD & Mean & SD & \\
\hline Frekuensi duduk & 2,59 & 0,864 & 2,59 & 0,864 & 0,000 \\
\hline Posisi pantat & 3,59 & 0,61 & 1,18 & 0,565 & 0,000 \\
\hline Kecukupan ketinggian kursi & 2,53 & 0,649 & 1,20 & 0,407 & 0,000 \\
\hline Perlunya adanya tambahan tinggi kursi & 2,76 & 0,855 & 1,98 & 3,81 & 0,000 \\
\hline Kecukupan jarak kursi dengan meja & 3,02 & 0,629 & 1,31 & 0,466 & 0,000 \\
\hline Perlunya adanya tambahan lebar kursi & 3,04 & 0,676 & 1,84 & 0,59 & 0,000 \\
\hline Keluhan pegal-pegal & 3,10 & 0,653 & 1,41 & 0,705 & 0,000 \\
\hline Keluhan nyeri & 2,78 & 0,896 & 1,37 & 0,698 & 0,000 \\
\hline Keluhan kesemutan & 2,35 & 0,991 & 1,33 & 0,689 & 0,000 \\
\hline Munculnya keluhan & 2,88 & 0,971 & 1,98 & 1,031 & 0,000 \\
\hline
\end{tabular}

\section{Hasil Pengujian Hipotesis Kuesioner Tingkat Kenyamanan}

Berikut adalah hasil pengujian hipotesis kuesioner tingkat kenyamanan dengan menggunakan uji wilcoxon. Hasil uji hipotesis untuk perbedaan nilai rata-rata sebelum dan sesudah redesain kursi gazebo FIK pada Tabel 2 diperoleh $p$ value $0,000(\mathrm{P} \leq 0,05)$ yang bermakna signifikan. Artinya, ada pengaruh redesain kursi gazebo FIK dengan tingkat kenyamanan mahasiswa FIK saat duduk di kursi gazebo FIK.

Tabel 2. Hasil Uji Hipotesis Kuesioner Tingkat Kenyamanan

\begin{tabular}{lcccc}
\hline \multicolumn{1}{c}{ Variabel } & N & Mean & SD & P Value \\
\hline Pretest & 49 & 28,63 & 3,480 & 0,000 \\
\hline Posttest & 49 & 16,37 & 3,365 & \\
\hline
\end{tabular}

\section{Hasil Pengukuran Antropometri} Mahasiswa FIK

Berdasarkan pengukuran antropometri pada 49 mahasiswa FIK diperoleh hasil sebagai berikut. Hasil uji untuk normalitas data antropometri mahasiswa
FIK pada Tabel 3 diperoleh bahwa $p$ value tinggi popliteal adalah $0,109(\mathrm{P} \geq$ $0,05)$ yang artinya data berdistribusi normal, dan $p$ value panjang popliteal $0,080 \quad(\mathrm{P} \geq 0,05)$ artinya data berdistribusi normal.

Tabel 3. Hasil Uji Normalitas Data Antropomteri Mahasiswa

\begin{tabular}{cccc}
\hline Variabel & Mean & SD & P Value \\
\hline Tinggi Popliteal & 41,02 & 2,817 & 0,109 \\
\hline Panjang Popliteal & 42,04 & 2,426 & 0,080 \\
\hline
\end{tabular}

Ukuran Kursi Gazebo FIK Sebelum dan Sesudah Redesain

Data antropometri mahasiswa pada Tabel 4 digunakan sebagai acuan dalam merancang kursi gazebo FIK yang ergonomis. Adapun data untuk ukuran kursi gazebo FIK yang ergonomis adalah sebagai berikut.

Tabel 4. Data Antropometri Mahasiswa

\begin{tabular}{cccc}
\hline \multirow{2}{*}{ Dimensi Kursi } & \multirow{2}{*}{ Dimensi Antropometri } & \multicolumn{2}{c}{ Persentil (cm) } \\
\cline { 3 - 4 } & & Ke-5 & Ke-95 \\
\hline Tinggi kursi & Tinggi popliteal & 36 & 45,65 \\
\hline Lebar kursi & Panjang popliteal & 38 & 46,04 \\
\hline
\end{tabular}


Berdasarkan pengukuran yang dilakukan oleh peneliti di kursi gazebo FIK sebelum dan sesudah kursi gazebo
FIK di redesain diperoleh hasil berikut ini.

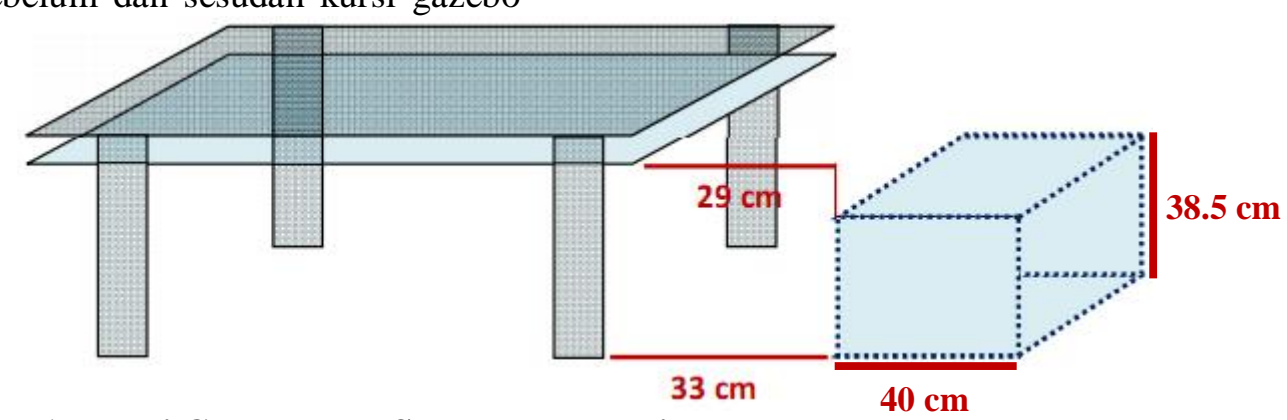

Gambar 1. Kursi Gazebo FIK Sebelum Redesain

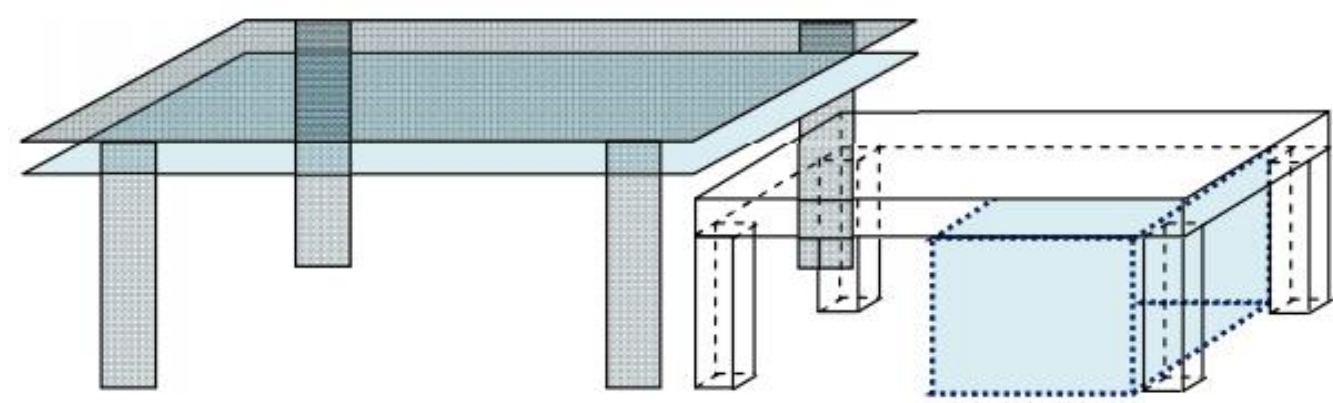

Gambar 2. Desain Kursi Gazebo FIK Setelah Ada Tambahan Kursi Gazebo FIK yang Ergonomis (Tampak Samping)

\section{Hasil Pengujian Hipotesis Kuesioner Nordic Body Map}

Hasil uji untuk perbedaan nilai sebelum dan sesudah redesain kursi gazebo FIK pada Tabel 5 diperoleh bahwa $p$ value adalah $0,000(\mathrm{P} \leq 0,05)$ yang bermakna signifikan. Artinya ada pengaruh redesain kursi gazebo FIK terhadap musculoskeletal disorders pada mahasiswa FIK UM.

Berdasarkan pengukuran keluhan musculoskeletal disorders sebelum dan sesudah redesain kursi gazebo FIK menggunakan kuesioner nordic body map didapatkan hasil sebagai berikut.

Tabel 5. Hasil Pengujian Hipotesis Kuesioner Nordic Body Map

\begin{tabular}{lcccc}
\hline \multicolumn{1}{c}{ Variabel } & N & Mean & SD & P Value \\
\hline Pretest & 49 & 46,29 & 13,123 & 0,000 \\
\hline Posttest & 49 & 32,76 & 32,76 & \\
\hline
\end{tabular}

\section{Hasil Persentase Keluhan Pada Setiap Bagian Otot Skeletal}

Sebelum adanya redesain kursi gazebo FIK, 61,22\% mengeluhkan sakit pada bagian bokong, 60,2\% mengeluhkan sakit pada bagian pinggang, 59,69\% mengeluhkan sakit pada bagian punggung, dan $48,47 \%$ mengeluhkan sakit pada bagian leher. Keluhan sakit pada bagian bokong menurun sebesar 26,02\%, menjadi $35,2 \%$, keluhan pada bagian pinggang mengalami penurunan mencapai $25,52 \%$ menjadi $34,69 \%$, keluhan sakit pada bagian punggung berkurang sebanyak $26,02 \%$ menjadi $33,67 \%$, dan keluhan sakit pada bagian leher berkurang $19,39 \%$ menjadi $29,08 \%$.

Berikut adalah persentase keluhan pada bagian otot skeletal yang paling banyak dirasakan oleh mahasiswa pada saat sebelum dan sesudah redesain kursi gazebo FIK. 
Tabel 6. Persentase Keluhan Pada Bagian Otot Skeletal Mahasiswa FIK Sebelum dan Sesudah Redesain Kursi Gazebo FIK

\begin{tabular}{lccc}
\hline \multicolumn{1}{c}{ Jenis Keluhan } & Sebelum $\mathbf{( \% )}$ & Sesudah $(\boldsymbol{\%})$ & Beda \\
\hline Bokong & 61,22 & 35,2 & 26,02 \\
\hline Pinggang & 60,2 & 34,69 & 25,51 \\
\hline Punggung & 59,69 & 33,67 & 26,02 \\
\hline Pantat & 59,18 & 33,67 & 25,51 \\
\hline
\end{tabular}

\section{PEMBAHASAN}

\section{Kondisi Subjek Penelitian}

\section{Frekuensi Duduk}

Bertahan pada posisi duduk dalam jangka waktu yang lama tanpa mengubah-ubah posisinya dapat menyebabkan kurangnya aliran darah pada suatu daerah (ischemia) (Panero, 2003). Gangguan pada sirkulasi darah dapat menyebabkan nyeri, sakit, dan rasa kebal (mati rasa). Berdasarkan kuesioner tingkat kenyamanan yang telah disebarkan kepada 49 responden, sebanyak 3 mahasiswa $(6,12 \%)$ dari seluruh sampel, yang duduk di gazebo FIK 1 kali dalam seminggu. Sebagian besar sampel, 23 mahasiswa $(46,94 \%)$ dari seluruh sampel, duduk di gazebo FIK 2-3 kali dalam seminggu. Sedangkan yang duduk di gazebo FIK selama 3-4 kali seminggu terdapat 14 mahasiswa $(28,57 \%)$. Dan mahasiswa yang duduk di gazebo FIK lebih dari 4 kali seminggu ada sebanyak 9 mahasiswa $(18,37 \%)$.

Apabila mahasiswa duduk dengan posisi yang statis selama \pm 30 menit tanpa beristirahat maka dapat menyebabkan keluhan nyeri punggung (Sumekar, 2010). Dalam penelitian yang dilakukan oleh Sumekar (2010) diperoleh hasil bahwa lama duduk berpengaruh terhadap nyeri punggung $(\mathrm{P}=0,006)$, dan lama duduk mempunyai risiko 18.497 kali lebih besar untuk terjadinya nyeri punggung. Dalam Jurnal Kedokteran Trisakti, Diana Samara (2004) juga menyimpulkan bahwa duduk lama terutama lebih dari 4 jam dengan sikap duduk membungkuk dapat menyebabkan nyeri punggung bawah.

Sebagian besar mahasiswa duduk di kursi gazebo FIK 2-3 kali dalam seminggu. apabila mahasiswa duduk di kursi gazebo FIK dengan frekuensi yang semakin sering maka dapat menyebab- kan risiko terkena gangguan muskuloskeletal lebih besar.

\section{Posisi Pantat Saat Duduk}

Tempat duduk harus dapat memberikan kenyamanan bagi pemakainya sehingga dapat mengurangi kelelahan orang yang duduk pada saat orang tersebut bekerja. Tempat duduk yang tidak nyaman dapat menyebabkan cedera punggung para pekerja. Lebar alas duduk yang tidak sesuai dengan antropometri pengguna dapat menyebabkan posisi pantat yang tidak pas dengan alas duduk, sehingga dapat menyebabkan postur tubuh saat duduk menjadi tidak ergonomis dan dapat menyebabkan gangguan muskuloskeletal. Berdasarkan Tabel 2 menunjukkan bahwa nilai rata-rata sebelum redesain sebesar 3,59 $\pm 0,61$ dan setelah redesain sebesar $1,18 \pm 0,565$, dan diperoleh $p$ value $0,000(\mathrm{P} \leq 0,05)$ yang bermakna siginifikan.

Duduk di kursi yang memiliki lebar tempat duduk yang lebih pendek daripada panjang pantat popliteal menyebabkan penopangan pada bagian paha tidak stabil, sehingga dapat menimbulkan ketidaknyamanan berupa perasaan terjungkal dari kursi. Apabila lebar tempat duduk lebih panjang daripada panjang pantat popliteal menyebabkan ujung kursi menekan daerah tepat di belakang lutut, sehingga dapat mengganggu proses peredarah darah (Panero, 2003). Lebih dari setengah sampel duduk dengan posisi pantat di ujung kursi, sehingga risiko yang dapat terjadi adalah terjatuh atau terjungkal dari kursi. Oleh karena itu, untuk mengurangi risiko terjatuh saat duduk di kursi gazebo FIK, dapat dilakukan penambahan lebar pada kursi gazebo FIK. 


\section{Kecukupan Ketinggian Kursi}

Tinggi tempat duduk yang tidak sesuai dengan antropometri pengguna dapat menyebabkan kaki menggantung ataupun kaki ditekuk akibat kursi yang terlalu pendek. Posisi tersebut merupakan posisi duduk yang tidak ergonomis dan dapat menyebabkan gangguan muskuloskeletal. Berdasarkan Tabel 2 menunjukkan bahwa nilai rata-rata sebelum redesain sebesar 2,53 $\pm 0,649$ dan setelah redesain sebesar $1,20 \pm$ 0,407 , dan diperoleh $p$ value 0,000 ( $\mathrm{P} \leq$ 0,05 ) yang bermakna siginifikan.

Duduk di kursi yang terlalu rendah dapat menyebabkan kaki akan memanjang ke depan. Posisi kaki yang memanjang ke depan dapat menyebabkan tubuh menjadi tidak stabil (Panero, 2003). Sedangkan apabila duduk di kursi yang terlalu tinggi dapat menyebabkan bagian bawah paha menjadi tertekan sehingga dapat menyebabkan gangguan peredaran darah dari tungkai bawah. Hal ini dapat menyebabkan ketidaknyamanan atau rasa ketidaknyamanan di paha, lutut, dan kaki (Dutta, 2012). Dalam penelitian yang dilakukan oleh Setyaningsih (2002), didapatkan kesimpulan bahwa ada hubungan positif bermakna antara tinggi alas duduk dengan tingkat nyeri pinggang, dengan $\mathrm{P}=0,018$ dan $\mathrm{R}=0,417$.

\section{Kecukupan Jarak Antara Kursi dengan Meja}

Kursi yang digunakan dengan meja secara bersamaan, selain memperhatikan tinggi dan alas duduk kursi juga perlu diperhatikan jarak antara kursi dengan meja. Jarak antara kursi dengan meja yang terlalu jauh menyebabkan posisi duduk menjadi membungkuk atau menyebabkan posisi pantat berada di ujung kursi. Berdasarkan Tabel 2 menunjukkan bahwa nilai rata-rata sebelum redesain sebesar 3,02 $\pm 0,629$ dan setelah redesain sebesar $1,31 \pm$ 0,466 , dan diperoleh $p$ value $0,000(\mathrm{P} \leq$ $0,05)$ yang bermakna siginifikan.

Jarak yang terlalu jauh antara kursi dengan meja membuat mahasiswa memposisikan duduknya lebih maju mendekati meja, sehingga posisi pantat saat duduk akan berada di ujung kursi. Posisi duduk yang demikian dapat menyebabkan penopangan pada bagian paha tidak stabil, sehingga dapat menimbulkan ketidaknyamanan berupa perasaan terjungkal dari kursi (Panero, 2003). Apabila mahasiswa memaksakan posisi duduknya untuk tidak mendekati meja maka posisi duduk yang terjadi adalah mahasiswa duduk dengan sikap membungkuk. Sikap punggung membungkuk akibat desain kursi yang tidak ergonomis, berisiko menyebabkan kesakitan pada punggung dan gangguan muskuloskeletal lainnya (Laura, 2005; Swinkels, 2006; Hurwitz, 2005; Koesyanto, 2013). Dalam penelitian yang dilakukan oleh Wardaningsih (2010), terdapat pengaruh sikap duduk pada kursi kerja yang tidak ergonomis terhadap gangguan muskuloskeletal bagi pekerja wanita bagian mesin cucuk di PT. Iskandar Indah Printing Textile Surakarta. Demikian juga penelitian yang dilakukan oleh Aditya (2012) menyebutkan bahwa sebagian besar pekerja bagian pelintingan rokok di PT. Djitoe Indonesia Tobacco mengalami keluhan nyeri punggung akibat sikap duduk yang tidak ergonomis. Dalam penelitian yang dilakukan oleh Martomijoyo (2016), disebutkan bahwa ada hubungan antara sikap kerja dengan keluhan nyeri punggung bawah pada pengrajin batik di PT. Paoman Art Kelurahan Paoman Kabupaten Indramayu. Oleh karena itu, untuk mengurangi jarak antara kursi gazebo FIK dengan meja dapat dilakukan penambahan lebar pada kursi gazebo FIK.

\section{Keluhan yang Dirasakan Saat Duduk}

Musculoskeletal disorders pada awalnya menyebabkan rasa sakit, nyeri, mati rasa, kesemutan, bengkak, kekakuan, gemetar, dan rasa terbakar. Salah satu faktor risiko yang dapat menyebabkan musculoskeletal disorders adalah postur kerja. Postur kerja yang tidak ergonomis dapat menyebabkan keluhan gangguan muskuloskeletal. 
Sikap kerja duduk yang tidak ergonomis akan menyebabkan gangguan tulang belakang. Hal tersebut disebabkan adanya tekanan pada tulang belakang yang meningkat pada saat duduk jika dibandingkan dengan saat berdiri (Purwanto, 2004; Nurjanah, 2012). Sikap duduk yang dipaksakan, seperti duduk dengan pantat diujung kursi atau duduk dengan sikap membungkuk, merupakan salah satu penyebab umum gangguan muskuloskeletal (Nurjanah, 2012). Apabila seseorang duduk dengan posisi yang tidak ergonomis maka akan merasa cepat mengalami kelelahan. Selain itu juga akan dirasakan keluhan seperti nyeri pada leher, kesemutan, pegal-pegal di lengan, dan anggota tubuh yang lain (Suryana, 2001; Nurjanah, 2012). Rasa nyeri pada otot terjadi akibat adanya suplai oksigen ke otot yang menurun, sehingga proses metabolisme karbohidrat menjadi terhambat dan sebagai akibatnya terjadi penimbunan asam laktat yang menyebabkan timbulnya rasa nyeri otot tersebut (Anies, 2005; Nurjanah, 2012).

\section{Analisis Kondisi Subjek Penelitian Sebelum dan Sesudah Redesain Kursi Gazebo FIK Berdasarkan Kuesioner Tingkat Kenyamanan}

Perencanaan desain kursi harus disesuaiakan dengan jenis pekerjaan, postur yang diakibatkan, gaya yang dibutuhkan, arah visual, dan kebutuhan akan perlunya merubah posisi (Nurmianto, 1996; Astutik, 2015). Alas yang tepat pada landasan tempat duduk dapat memenuhi kebutuhan tersebut dan juga harus diupayakan duduk dapat mengubah posisinya atau postur tubuhnya untuk mengurangi rasa ketidaknyamanannya (Astutik, 2015). Desain kursi yang tidak tepat akan menyebabkan sakit punggung dan masalah tulang belakang. Desain kursi yang tepat ditandai dengan perasaan nyaman apabila individu duduk di kursi itu dalam jangka waktu yang lama (Puswiartika, 2008). Oleh karena itu, dalam mendesain kursi yang ergonomis harus disesuaikan dengan antropometri pengguna, sehingga dapat mengurangi risiko terkena gangguan muskuloskeletal.
Berdasarkan hasil kuesioner tingkat kenyamanan sebelum redesain kursi gazebo FIK diperoleh rerata $(\mathrm{X}) \pm$ SD yaitu 28,63 $\pm 3,480$, dan hasil kuesioner tingkat kenyamanan sesudah redesain kursi gazebo FIK diperoleh rerata $(X) \pm$ SD yaitu $16,37 \pm 3,365$. Hasil uji untuk perbedaan nilai pretest dan posttest sebelum dan sesudah redesain kursi Gazebo FIK dengan menggunakan uji Wilcoxon diperoleh bahwa $\mathrm{P}$ Value adalah $0,000(\mathrm{P} \leq 0,05)$ yang bermakna signifikan. Artinya ada pengaruh redesain kursi Gazebo FIK terhadap musculoskeletal disorders pada mahasiswa FIK UM.

\section{Analisis Antropometri Mahasiswa dengan Kursi Gazebo FIK}

Berdasarkan data antropometri mahasiswa FIK dan ukuran atau dimensi kursi gazebo FIK, maka dapat dianalisis ada atau tidaknya kesesuaian antara dimensi kursi gazebo dengan dimensi tubuh mahasiswa FIK sebagai pengguna beserta persentil yang akan digunakan dalam perancangan desain kursi gazebo FIK yang ergonomis.

\section{Tinggi Tempat Duduk}

Tinggi tempat duduk harus memiliki panjang yang lebih pendek dari panjang tekuk lutut sampai telapak kaki. Secara antropometrik, tinggi tempat duduk dapat diukur dengan mengukur tinggi lipatan dalam lutut atau yang disebut dengan tinggi popliteal. Tinggi popliteal dapat diukur secara vertikal dari permukaan lantai sampai dengan bagian bawah paha tepat dibagian belakang lutut (Panero, 2003). Persentil yang digunakan untuk tinggi tempat duduk adalah persentil ke-5, yang artinya 5\% dari populasi berada sama atau lebih rendah dari persentil ke-5. Penggunaan persentil ke-5 akan menciptakan kondisi tinggi kursi yang dapat diakomodasi bagi mahasiswa dengan ukuran tinggi popliteal yang paling pendek. Selain itu juga dapat diakomodasi bagi mahasiswa dengan ukuran tinggi popliteal yang lebih tinggi.

Tinggi kursi gazebo FIK sebelum redesain $38,5 \mathrm{~cm}$ dan untuk tinggi popliteal pada persentil ke-5 sebesar 
$36,39 \mathrm{~cm}$. Dengan demikian tinggi kursi gazebo FIK sebelum redesain lebih tinggi daripada tinggi popliteal mahasiswa FIK pada persentil ke-5 $(38,5 \mathrm{~cm}>36,39 \mathrm{~cm})$ sehingga dapat dikatakan bahwa tinggi kursi gazebo FIK yang digunakan tidak ergonomis.

Namun, lebih dari $60 \%$ mahasiswa merasa perlu penambahan tinggi kursi gazebo FIK. Hal ini dapat dikarenakan dalam penentuan ukuran tinggi kursi, selain mempertimbangkan dimensi tinggi popliteal, juga perlu diperhatikan alas kaki yang digunakan. Dalam buku Dimensi Manusia \& Ruang Interior (Panero, 2003) disebutkan bahwa tambahan tinggi popliteal dapat ditambahkan ukuran sebesar 1,5 inci atau $3,8 \mathrm{~cm}$ menjadi $40,2 \mathrm{~cm}$. Selain itu, apabila kursi digunakan bersamaan dengan meja, maka ukuran tinggi kursi juga harus mempertimbangkan tinggi meja yang digunakan. Tinggi meja gazebo FIK sebesar $77 \mathrm{~cm}$, sehingga alas duduk dengan alas meja memiliki jarak sebesar $38,5 \mathrm{~cm}$. jarak antara alas duduk dengan meja dapat ditentukan melalui tinggi siku pada posisi istirahat. Jarak maksimal antara alas duduk dengan meja yang diperkenankan dalam buku Dimensi Manusia \& Ruang Interior sebesar $28 \mathrm{~cm}$. Artinya, jarak yang antara alas duduk dengan meja saat ini mencapai $10,6 \mathrm{~cm}$. Dengan berbagai pertimbangan tersebut, maka redesain untuk ketinggian kursi gazebo FIK dapat dilakukan dengan penambahan tinggi sebesar $7 \mathrm{~cm}$.

Tinggi tempat duduk yang tidak ergonomis akan menimbulkan sikap duduk yang tidak ergonomis pula, seperti berikut ini.

a. Akibat kursi terlalu pendek menyebabkan kaki selonjor memanjang ke depan. Posisi tersebut dapat menimbulkan kestabilan tubuh menjadi berkurang (Panero, 2003).

b. Selain itu, akibat kursi yang terlalu pendek, juga dapat menyebabkan kaki ditekuk. Ketika kaki ditekuk maka dapat menghentikan aliran darah dan menyebabkan kesemutan (Wardaningsih, 2010).

c. Akibat kursi yang terlalu tinggi akan menyebabkan kaki menggantung dan dapat menyebabkan paha tertekan sehingga peredaran darah menjadi terhambat (Panero, 2003). Posisi demikian dapat menimbulkan keluhan berupa nyeri dan pegal-pegal pada kaki (Wardaningsih, 2010:56).

\section{Leba Tempat Duduk}

Lebar tempat duduk harus lebih pendek dari lipatan dalam lutut sampai dengan garis punggung. Secara antropometrik, lebar tempat duduk dapat diukur dengan mengukur jarak dari pantat ke lipatan dalam lutut atau panjang popliteal. Panjang popliteal dapat diukur dari bagian depan sampai bagian belakang sebuah tempat duduk atau jarak horizontal dari permukaan paling belakang pantat hingga bagian belakang dari kaki bagian bawah (Panero, 2003). Persentil yang digunakan untuk lebar tempat duduk adalah persentil ke-5, yang artinya 5\% dari populasi berada sama atau lebih rendah dari persentil ke-5. Penggunaan persentil ke-5 akan menciptakan kondisi lebar kursi yang dapat diakomodasi bagi mahasiswa dengan ukuran panjang popliteal yang paling pendek. Selain itu juga dapat diakomodasi bagi mahasiswa dengan ukuran panjang popliteal yang lebih lebar.

Lebar kursi gazebo FIK sebelum redesain $40 \mathrm{~cm}$ dan untuk panjang popliteal pada persentil ke-5 sebesar 38 $\mathrm{cm}$. Dengan demikian lebar kursi gazebo FIK sebelum redesain lebih lebar daripada panjang popliteal mahasiswa FIK pada persentil ke-5 $(40 \mathrm{~cm}>38 \mathrm{~cm})$ sehingga dapat dikatakan bahwa lebar kursi gazebo FIK yang digunakan tidak ergonomis.

Namun, lebih dari $80 \%$ mahasiswa merasa perlu penambahan lebar kursi gazebo FIK. Hal ini dapat dikarenakan dalam penentuan ukuran lebar kursi, selain mempertimbangkan dimensi panjang popliteal, juga perlu diperhatikan jarak antara kursi dengan meja yang digunakan. Jarak antara kursi dengan meja sebesar $32 \mathrm{~cm}$. Seharusnya tidak ada jarak antara kursi dengan meja. Dengan berbagai pertimbangan tersebut, maka redesain untuk lebar kursi gazebo 
FIK dapat dilakukan dengan penambahan lebar sebesar $32 \mathrm{~cm}$.

Lebar tempat duduk yang tidak ergonomis akan menimbulkan sikap duduk yang tidak ergonomis pula, seperti:

a. Akibat lebar kursi terlalu pendek menyebabkan kurangnya penopang pada bagian bawah paha. Posisi tersebut dapat menimbulkan perasaan terjatuh atau terjungkal dari kursi (Panero, 2003).

b. Selain itu, akibat lebar kursi yang terlalu pendek, juga dapat menyebabkan posisi paha yang seharusnya lurus menjadi cenderung miring ke bawah dan kaki menjadi tumpuan. Hal ini dapat menyebabkan keluhan di bagian bokong, pantat, dan juga paha (Wardaningsih, 2010).

c. Akibat kursi yang terlalu lebar akan menyebabkan bagian ujung dari kursi menekan daerah di belakang lutut sehingga peredaran darah menjadi terhambat (Panero, 2003).

\section{Analisis Keluhan Pada Masing-Masing Bagian Otot \\ 1. Sebelum Redesain Kursi Gazebo FIK}

Posisi tubuh yang salah dan duduk terlalu lama saat kuliah dan belajar merupakan salah satu faktor risiko gangguan muskuloskeletal. Posisi tubuh yang membungkuk atau tidak tegak saat duduk dapat terjadi akibat desain kursi yang tidak sesuai dengan antropometri mahasiswa.

Sebelum adanya redesain kursi gazebo FIK, 61,22\% mengeluhkan sakit pada bagian bokong, 60,2\% mengeluhkan sakit pada bagian pinggang, 59,69\% mengeluhkan sakit pada bagian punggung, dan $48,47 \%$ mengeluhkan sakit pada bagian leher. Akibat posisi pantat berada di ujung kursi pada saat duduk di kursi gazebo FIK maka mahasiswa mengeluhkan sakit pada bagian bokong dan juga pinggang. Tidak adanya sandaran kursi dapat menyebabkan munculnya keluhan nyeri punggung (Dutta, 2012). Pada penelitian yang dilakukan oleh Samara (2007) dapat disimpulkan bahwa nyeri leher yang dirasakan oleh pekerja terjadi akibat adanya ketegangan dan peregangan otot disekitar leher. Salah satu jenis pekerjaan yang dapat memicu terjadinya nyeri leher antara lain bekerja didepan meja dengan posisi membungkuk. Gejala nyeri leher antara lain terasa sakit dan kaku di daerah leher, nyeri pada otot-otot leher, sakit kepala, dan migraine. Nyeri bisa menjalar ke bahu, lengan, dan tangan disertai keluhan terasa baal atau seperti ditusuk jarum.

Selain itu, adanya ketidaksesuaian antara dimensi tubuh mahasiswa FIK dengan dimensi kursi gazebo FIK dapat menyebabkan ketidaknyamanan tubuh mahasiswa saat duduk di kursi gazebo FIK, sehingga mahasiswa harus sering mengubah posisi duduknya (Dutta, 2012). Hal tersebut dilakukan untuk menciptakan kondisi yang lebih nyaman.

\section{Setelah Redesain Kursi Gazebo FIK} Menurut OSHA (2000), gangguan muskuloskeletal dapat terjadi ketika kemampuan fisik seseorang tidak sebanding dengan pekerjaan yang dilakukan. Postur yang tidak ergonomis (awkward postures) dapat menekan syaraf dan mengiritasi tendon. Selain itu postur statis, seperti duduk dengan posisi yang tetap selama beberapa menit dapat mengganggu aliran darah dan merusak otot (OSHA, 2000). Gangguan muskuloskeletal salah satunya dapat dicegah dengan cara engineering control, yakni menggunakan peralatan dan stasiun kerja yang sesuai dengan antropometri pengguna (OSHA, 2000).

Oleh karena itu, setelah adanya redesain kursi gazebo FIK, berupa penambahan ketinggian kursi dan lebar kursi sesuai dengan antropometri mahasiswa, maka keluhan gangguan muskuloskeletal mahasiswa FIK mengalami penurunan. Keluhan sakit pada bagian bokong menurun sebesar $26,02 \%$, dari $61,22 \%$ menjadi $35,2 \%$, keluhan pada bagian pinggang mengalami penurunan mencapai $25,52 \%$ menjadi 34,69\%, keluhan sakit pada bagian punggung berkurang sebanyak $26,02 \%$ menjadi $33,67 \%$, dan keluhan 
sakit pada bagian leher berkurang $19,39 \%$ menjadi $29,08 \%$.

Hal ini didukung oleh penelitian yang telah dilakukan oleh Pratomo (2007) yang meneliti tentang "Hubungan Antara Kursi Kerja dengan Timbulnya Keluhan Nyeri Pinggang Pada Pekerja Tenun Kain Sarung di Java ATBM (Alat Tenun Bukan Mesin) Desa Kebunan Kecamatan Taman Kabupaten Pemalang". Hasil analisis uji statistik menunjukkan nilai $\mathrm{p}=0,02$ yang artinya ada hubungan antara kursi kerja dengan timbulnya keluhan nyeri pinggang pada pekerja tenun kain sarung. Hasil penelitian ini juga mendukung penelitian sebelumnya yang dilakukan oleh Subagya (2010) tentang "Pengaruh Ergonomis Stasiun kerja terhadap Keluhan otot-otot skeletal Pekerja lakilaki Kantor Administrasi Dokumen Building PT Krakatau Steel Cilegon", dengan hasil uji statistik nilai $\mathrm{p}=0,000$ $(\mathrm{p}<0,05)$, maka hasil uji dinyatakan signifikan, yang artinya ada beda ratarata antara skor keluhan muskuloskleletal sebelum bekerja dengan setelah bekerja.

\section{Analisis Keluhan Musculoskeletal Disorders Sebelum dan Sesudah Redesain Kursi Gazebo FIK Berdasarkan Kuesioner Nordic Body Map}

Desain kursi yang tidak tepat akan dapat menyebabkan sakit punggung dan masalah tulang belakang. Akibat desain kursi yang tidak sesuai dengan antropometri pengguna, maka dapat menimbulkan sikap duduk yang salah. Posisi tubuh yang salah selama duduk membuat tekanan abnormal dari jaringan sehingga menyebabkan rasa sakit (Astutik, 2015).

Berdasarkan hasil kuesioner Nordic Body Map sebelum redesain kursi gazebo FIK diperoleh rerata $(\mathrm{X}) \pm \mathrm{SD}$ yaitu 46,29 $\pm 13,123$, dan hasil kuesioner Nordic Body Map sesudah redesain kursi gazebo FIK diperoleh rerata $(\mathrm{X}) \pm \mathrm{SD}$ yaitu $32,76 \pm 32,76$. Hasil uji untuk perbedaan nilai pretest dan posttest sebelum dan sesudah perlakuan dengan menggunakan uji Wilcoxon diperoleh bahwa $\mathrm{P}$ Value adalah $0,000(\mathrm{P} \leq 0,05)$ yang artinya signifikan. Maka dapat disimpulkan bahwa terdapat pengaruh redesain kursi gazebo FIK terhadap keluhan musculoskeletal disorders pada mahasiswa FIK UM.

Hal ini dapat terjadi karena redesain kursi telah disesuaikan dengan antropometri mahasiswa FIK sebagai pengguna. Penelitian sejenis dilakukan oleh Wulandari (2016) dengan judul "Pengaruh redesain kursi kerja terhadap keluhan musculoskeletal pada pekerjaan menjahit di desa X". Hasil penelitian ini menunjukkan bahwa ada pengaruh redesain kursi kerja terhadap keluhan muskuloskeletal pada pekerjaan menjahit di desa $X$ dengan nilai $P$ Value 0,001 yang artinya ada beda yang sangat signifikan. Penelitian sejenis juga dilakukan oleh Pratomo (2007) dengan judul "Hubungan Antara Kursi Kerja dengan Timbulnya Keluhan Nyeri Pinggang Pada Pekerja Tenun Kain Sarung di Java ATBM (Alat Tenun Bukan Mesin) Desan Kebunan Kecamatan Taman Kabupaten Pemalang". Hasil penelitian ini menunjukkan bahwa ada hubungan antara kursi kerja dengan timbulnya keluhan nyeri pinggang pada pekerja tenun kain sarung dengan hasil analisis uji statistik p sebesar 0,02 .

\section{PENUTUP}

Berdasarkan hasil penelitian dan analisis data pada kuesioner kenyamanan penggunaan kursi gazebo FIK dan kuesioner nordic body map sebelum dan sesudah redesain dapat disimpulkan bahwa ada pengaruh redesain kursi gazebo FIK terhadap keluhan musculoskeletal disorders pada mahasiswa FIK UM.

Adapun berikut merupakan saran yang dapat disampaikan.

\section{Bagi Fakultas Ilmu Keolahragaan}

Penggunaan kursi gazebo FIK yang ergonomis dalam penelitian ini terbukti dapat menurunkan skor ketidaknyamanan, sehingga bagi Fakultas Ilmu Keolahragaan dapat memperbaiki atau menambahkan kursi sesuai dengan desain yang ada pada penelitian ini. 


\section{Bagi Mahasiswa Fakultas Ilmu Keolahragaan}

Hendaknya bagi para mahasiswa menggunakan kursi yang ergonomis saat duduk di gazebo FIK disertai dengan menerapkan posisi duduk yang benar.

\section{Bagi Peneliti Selanjutnya}

Bagi peneliti selanjutnya, hendaknya dapat menambahkan variabel lain seperti sandaran, pijakan kaki, dan juga pemberian busa pada alas duduk. Tujuannya agar dapat meminimalisasi ketidaknyamanan yang lebih baik lagi.

\section{DAFTAR PUSTAKA}

Aditya. 2012. Pengaruh Sikap Kerja Duduk Terhadap Keluhan Nyeri Punggung Bawah Pada Pekerja Bagian Pelintingan Rokok Di Pt. Djitoe Indonesia Tobacco. Naskah Publikasi. Surakarta: Universitas Muhammadiyah Surakarta.

Astuti. 2009. Gambaran Faktor Risiko Pekerjaan dan Keluhan Gejala Musculoskeletal Disorders pada Tubuh Bagian Atas Pekerja di Sektor Informal Butik Lamode, Depok Lama, Tahun 2009. Skripsi. Jakarta: Universitas Indonesia.

Astutik., Sugiharto. 2015. Hubungan antara Desain Kursi Kerja dengan Keluhan Nyeri Punggung Bawah Pada Pekerja Bagian Penenunan di CV. Pirsa Art Pekalongan. Unnes Journal of Public Health, 4 (1): 61-68.

Dutta S, Dhara PC. 2012. Evaluation of Different Sitting Postures of Rural Primary School Boys in the Classroom. Journal of Ergonomics, 2: 105 . doi: 10.4172/2165-7556.1000105.

Health and Safety Executive. 2012. Musculoskeletal Disorder. (Online),

(http://www.hse.gov.uk/offshore/m usculoskeletal.htm), diakses 13 Juni 2017.

Health and Safety Executive. 2015. Work Related Musculoskeletal Disorder Statistics (WRMSDs) in Great Britain 2015. (Online), (http://www.hse.

gov.uk/statistics/causdis/musculos

keletal/index.htm), diakses 2 November 2016.

Iridiastadi, Hardianto. Yassierli. 2014. Ergonomi Suatu Pengantar. Bandung: Rosda Jaya Putra.

Koesyanto. 2013. Masa Kerja Dan Sikap Kerja Duduk Terhadap Nyeri Punggung. Jurnal Kemas, 9 (1): 914.

Lisdiana, S. 2013. Pengaruh Penggunaan Kursi Ergonomis Terhadap Kenyama-nan Posisi Duduk Pada Ibu Menyusui Bayi Sampai Usia Enam Bulan di Kelurahan Pisangan Kecamatan Ciputat Timur Kota Tangerang Selatan Tahun 2013. Skripsi. Jakarta: UIN Syarif Hidayatullah.

Martomijoyo. 2016. Hubungan Sikap Kerja Dengan Keluhan Nyeri Punggung Bawah Pada Pengrajin Batik PT Paoman Art Di Kelurahan Paoman Kabupaten Indramayu. Jurnal Universitas Wiralodra, 7 (4): 68-71.

NIOSH. 2015. Hierarchy Of Control. (Online),

(https://www.cdc.gov/niosh/ topics/ hierarchy/), diakses 13 Oktober 2016.

Nurjanah. 2012. Hubungan Sikap Kerja Duduk dengan Keluhan Musculoskeletal Pada Pekerja Bagian Reaching PT. Delta Merlin Dunia Textile Kebakkramat Karanganyar. Skripsi. Surakarta: Universitas Sebelas Maret.

Occupational Safety and Health Administration. 2000. Ergonomic: The Study of Work. (Online), (https://www.osha.gov/Publication s/osha3125.pdf), diakses 15 Juni 2017.

Panero, Julius., Zelnik, Martin. 2003. Dimensi Manusia dan Ruang Interior. Erlangga: Jakarta.

Pratomo. 2007. Hubungan Antara Kursi Kerja Dengan Timbulnya Keluhan Nyeri Pinggang Pada Pekerja Tenun Kain Sarung Di Java Atbm (Alat Tenun Bukan Mesin) Desa Kebunan Kecamatan Taman 
Kabupaten Pemalang Tahun 2006. Skripsi. Semarang: Universitas Negeri Semarang

Puswiartika, D. 2008. Peran Ergonomi dalam Meningkatkan Produktivitas Kerja. Ragam Jurnal Pengembangan Humaniora, 8 (1).

Samara, Diana. 2004. Lama Dan Sikap Duduk Sebagai Faktor Risiko Terjadinya Nyeri Pinggang Bawah. Jurnal Kedokteran Trisakti, 23 (2): 63-67.

Samara, Diana. 2007. Nyeri Muskuloskeletal Pada Leher Pekerja Dengan Posisi Pekerjaan Yang Statis. Jurnal Universa Medicina, 26 (3): 137-142.

Setyaningsih. 2002. Hubungan Sikap Kerja Duduk Dengan Tingkat Nyeri Pinggang Pada Pekerja Laki-Laki Bagian Produksi Perusahaan Keramik (Studi Kasus Pada Industri Kerajinan Keramik di Kecamatan Purwareja Klampok Kabupaten Banjarnegara Tahun 2001). Skripsi. Semarang: Universitas Diponegoro.

Sari, Retna. 2013. Studi Aktivitas Pengguna Gazebo Fakultas Pendidikan Teknologi Dan Kejuruan. Skripsi. Jakarta: Universitas Pendidikan Indonesia.

Solichin., Kustono, Djoko., Martiningsih, Anny. 2014. Dasar-Dasar Keselamatan dan Kesehatan Kerja. Malang: Universitas Negeri Malang.

Subagya, Anang. 2010. Pengaruh Stasiun Kerja Terhadap Keluhan OtotOtot Skeletal Pekerja Laki-Laki Pada Kantor Administrasi Dokumen Building PT. Krakatau Steel Cilegon. Skripsi. Surakarta: Universitas Sebelas Maret.

Sugiyono. 2011. Metode Penelitian Kuantitatif dan Kualitatif. Bandung: CV. Alfabeta.

Suliyanto. 2014. Statistik Non Parametrik dalam Apilkasi Penelitian. Yogyakarta: ANDI.

Sumekar, D. \& Natalia, D. 2010. Nyeri Punggung pada Operator Komputer Akibat Posisi dan Lama
Duduk. Bandung Medical Journal, 42 (3): 123-127.

Tim Penyusun Pedoman Karya Tulis Ilmiah. 2010. Pedoman Karya Tulis Ilmiah. Malang: UM PRESS.

Wiranata. 2011. Redesain Kursi Kuliah Ergonomis dengan Pendekatan Anthropometri. Skripsi. Surakarta: Universitas Sebelas Maret.

Wardaningsih. 2010. Pengaruh Sikap Kerja Duduk Pada Kursi Kerja Yang Tidak Ergonomis Terhadap Keluhan Otot-Otot Skeletal Bagi Pekerja Wanita Bagian Mesin Cucuk Di PT Iskandar Indah Printing Textile Surakarta. Skripsi. Surakarta: Universitas Sebelas Maret.

Wulandari., Rosanti. 2016. Pengaruh Redesain Kursi Kerja Terhadap Keluhan Muskuloskeletal Pada Pekerjaan Menjahit Di Desa X. Journal of Industrial Hygiene and Occupational Health, 1 (1): 23-39. 